UDC [94(477.52)(093.4):347.67]

DOI 10.32755/sjeducation.2020.01.137

Popruzhna A.,

$\mathrm{Ph}$. D. in History, Associate Professor of the Department of Economics and Social Disciplines of the Academy of the State Penitentiary Service, Chernihiv, Ukraine ORCID: 0000-0002-5079-2865

\title{
MEMORY PERPETUATING IN GRAVESTONE PORTRAITS AS ATTRIBUTE OF THE COSSACK ELITE'S FUNERAL CULTURE OF THE SECOND HALF OF THE 17th-18th CENTURIES
}

The article deals with the gravestone portraits of the representatives of the Cossack Elite of the second half of the seventeenth and eighteenth centuries as the attributes of its funeral culture.

The purpose of the article is to analyze the mechanisms of memory perpetuating and honoring of the dead representatives of the Cossack Elite, ascertaining the role of local traditions and external influences in the formation of the Cossack Elite's funeral culture of the second half of the 17th-18th centuries.

Gravestone portraits studying will contribute to a better understanding of a funeral culture as a social and cultural phenomenon of the early modern era that included preparation for death, mourning ceremonies, and memory perpetuating and honoring of the deceased.

It was concluded that the representatives of the leading social stratum of the Hetmanate had ordered the gravestone portraits when they were alive, following the superstition to portray the face of the portrayed person after his death. The gravestone portraits could also be ordered by relatives after the death of a person. The use of the portraits in the mourning ceremony was a way of memory perpetuating and an occasion to recall the charity of the deceased.

Key words: funeral culture, Cossack Elite, a gravestone portrait.

According to Christian beliefs, death and funeral did not interrupt the connection between alive and dead people that was preserved due to commemoration in synodics, memory perpetuating in gravestone portraits and epitaphs.

In the second half of the 17th-18th centuries the necessary attribute of the funeral culture of the wealthy Cossacks were the portraits that were placed in temples and monasteries over the graves of the representatives of the Cossack Elite.

The gravestone portraits are mentioned in the works of K. Shyrotskyi [35], O. Lazarevskyi [13-17], V. Horlenko [3], A. Storozhenko [29], M. Storozhenko [30], D. Shcherbakivskyi [34], 
F. Ernst [34]. Among contemporary cognoscenti, some attention was paid to them by P. Bileczkyi [2], L. Tananaieva [32], B. Ivanova [7], R. Kosiv [11], O. Sukhovarova-Zhornova [31], O. Pokhodiashcha [22-23], M. Dmytriienko [5], A. Zverkhovska [6], D. Semeniuk [26], O. Gava [4], Yu. Osadcha [21], I. Netudykhatkin [19].

The gravestone portraits were an important element of the Cossack Elite's funeral culture of the second half of the 17th-18th centuries. Tradition to leave on memory of the deceased a gravestone portrait or a "konterfect", a "shtuka", a "parsuna" was rather old. D. Shcherbakivskyi thought that it originated from Ancient Egypt. It is also assumed that this tradition comes from the "depths of Italian culture" [26, p. 48]. In Italy, it has long been customary to install a sculpture portrait on the grave. Then, a tradition to hang out on the wall of the church, in which a deceased was buried, a tablet with the bas-relief of a dead person, appeared.

Shyrotskyi K. noted that portraiture images were used in the funeral ceremonies of Polish Szlachta: "On the grave of a deceased a carved sculpture ... or a written portrait was put" [35, p. 199]. Often, the bust of a deceased was painted on a metal or wood and was placed on the side of a coffin [26, p. 49]. Such gravestone portraits were inherent in the funeral ceremonies of the nobility from the end of the 16th century" [36]. Some portraits connected with mourning ceremonies included the depiction of a deceased person on a hearse [7, p. 217].

In the 16th-18th centuries portraits were part of dramatized mourning ceremonies ("pompa funebris") of Polish Szlachta. It was through the funeral that leading social communities such as: Polish Szlachta, and later Ukrainian Cossack Elite tried to show their high status.

One of the varieties of the portraits used by Polish Szlachta during the funeral ceremonies were the so-called portraits made on the coffin. They were ordered after the death of a person and were fixed directly at the edge of a coffin, repeating its shape, from the head of a deceased. They painted such portraits at hexagonal or octagonal tin, zinc, silver plated and silver plaques, $40 \times 40 \mathrm{~cm}$ in size, and only a human bust was depicted. 
For the first time, such a portrait was installed at the edge of the coffin of King Stephen Bathory in 1586 [26, p. 50]. Gradually the portrait became a part of the funeral ritual, played the role of a "twin" of a deceased and symbolized the continuation of his life. After funeral, such a portrait was usually transferred to a family chapel or church. However, the highest manifestation of the "funeral theater" at the lands of the Polish-Lithuanian Commonwealth among Polish Szlachta was the appearance of a dressed man, looked like a deceased, who seemed to "see himself off" [35, p. 198-202].

The birth of the Cossack Elite as a social elite took place in the society of the Polish-Lithuanian Commonwealth. And if the Cossacks, who led "semi-ascetic way of life, formed contempt for "Polish lordly traditions", theatrical rituals associated with the funeral" [11, p. 69], then the funeral culture of the representatives of the Cossack Elite of the second half of the $17^{\text {th }}-18$ th centuries absorbed the traditions of a mourning ceremony of Polish Szlachta. However, it is known that even ordinary Cossacks had the habit of hanging a flag or a kerchief on the grave of a deceased: "we placed the flag, and so we honored the knight" [35, p. 200].

In the second half of the 17th-18th centuries the gravestone portraits began to be placed in temples over the graves of the representatives of Cossack Elite. According to the researchers, they appeared in Ukraine as a result of parallel efforts of Western European and Orthodox traditions [34, p. 8]. However, mourning ceremonies among the Cossack Elite were less pompous than in the Polish-Lithuanian Commonwealth, and the tradition of perpetuating the dead representatives of the Cossack Elite in portraits had its own peculiarities. In particular, the use of metal portraits made on the coffin in a funeral ritual did not become much widespread. Instead, this tradition was preserved by the citizens, which is approved by a collection of portraits made on the coffin of the members of Lviv Stauropegion Brotherhood [26, p. 48]. A bust image on a tin hexahedron of a Metropolitan Ioann Maksymovych, discovered in his tomb in St Sophia-Assumption Cathedral in Tobolsk is also known [25, p. 258].

Probably the appearance of the gravestone portraits was preceded by gonfalons. In this context, one should pay attention to the 
mentions of Petro Konashevych-Sahaidachnyi (1622) and Tymosh Khmelnytskyi's (1653) "horse" gonfalons [33, p. 25]. The gonfalon of Nizhyn Colonel Ivan Hulianytskyi (1677) with the epitaphical inscription also belonged to this type [11, p. 74]. A gravestone portrait with or without an epitaph "was a kind of a painting monument that was installed in the church in order to emphasize that the depicted person was buried here" [34, p. 10].

Above the grave of Bohdan Khmelnytskyi in Illinska church in Subotiv under the canopy his portrait with an epitaphical inscription was placed, according to the author of "The Story of Russ". It was said:

"Sey obraz nachertan Kozatskogo Geroya,

Podobno grekam tem, ot koikh pala Troya!

Pompey i Tsesar, chto byli u Rimi,

U Russov znachil to Khmelnitskiy delami svoimi:

Polshchu on nizlozhil kozatskimi polkami,

Tatar i Turkov ustrashil temi zhe voyskami;

Nakazav varvarstvo, presek virolomstvo,

Vechno ne zabudet to Polskoye potomstvo.

Uniyu on oproverg, blagochestiye vozstavil,

Revnost v tom svoyu v rode proslavil;

Nepobedim vo braniakh, blagoy vospriyal konets:

Iz sina v otechestve dostoyneshiy yemu yavilsia otets!» [8, p. 115]

Shyrotskyi K. associated the birth and formation of the portrait art in Ukraine in the 14th-16th centuries with the funeral ritual and the fact of death. He attracted attention to it at the beginning of the 20th century [35, p. 198]. A well-known Ukrainian historian O. Ohloblin also emphasized that in "Mazepa's Era" portrait painting achieved special success [20, p. 134].

In Cossack Ukraine, a portrait associated with funeral traditions was conceived mainly as a part of the temple rather than the farmstead interior. Often portraits were painted in several variants: for the home and for the church or monastery. Usually the right to place the portraits in the monasteries belonged to founders.

Shyrotskyi K. suggested that most of the old portraits were posthumous and were a part of Cossacks' funeral ceremony. The details of the portrait (clothing, weapons) were partly depicted during 
the life of the customer, but they were depicted after his death. Therefore, the face and body shape are painted carelessly for some reason $[35$, p. 200]. It could be painted from a face of a dead person, in memory or from the lifetime original.

"The most often they painted the portraits of the deceased on a wood or on canvas and hang them on the wall in the church, and during the processions they sometimes wore them around the church, along with the icons. Very rarely they portrayed a deceased with his eyes closed, as usual, he was painted at full height with piously folded hands in front of a cross. There were appropriate inscriptions, poems or epitaphs below... D. Shcherbakivskyi and F. Ernst believed that in general most of old portraits that really were a part of both Szlachta and Cossacks' funeral ceremony are such posthumous portraits" [34, p. 10].

Biletsky P. noticed that the preparatory picture to the portrait of Sumy Colonel Herasym Kondratiev was created by a painter when he was in the deathbed. Such an effect of an "unseen look" (drawing a painting looking at a dead person) is also characteristic of other gravestone portraits [2, p. 13]. Probably, the lost gravestone portraits of General Treasurer Yakiv's Markovych father Marko Avramovych, who died in 1712 and buried in the Hustynskyi Monastery, a significant military comrade Illia Novytskyi, who died before 1704 were created in such a way [12, p. 231].

Netudykhatkin I. admitted that most of the portraits of the representatives of Cossack Elite were written after their death. He, in particular, considered the bust portrait of the General Oboznyi Vasyl Dunin-Borkovskyi to be such a portrait [19, p. 5-9].

During the mourning ceremony, a portrait was carried behind a coffin. Later, it was placed in the interior of a temple that was near a grave. Horlenko V. noted: "Our ancient churches and monasteries sometimes keep the samples of old portrait painting" [3, p. 602-603].

Both the gravestone portraits depicting a deceased in full height, and later bust gravestone portraits were placed in churches in such a way the epitaph was at the level of the viewer's eyes. However, after 10 years, due to the sharp temperature fluctuations and smoke from the candles, it was almost impossible to recognize a depicted person 
and to read the epitaph inscription. In such cases, they wanted to create a copy of the gravestone portrait [2, p. 137].

Storozhenko A. approved Horlenko's V. opinion in the essay "Mikhailovskaya and Pokrovskaya churches in Pereyaslav of Poltava province", published on the pages of the newspaper "Kievan olden": "The portraits of not only saints, but also of contemporary persons in church painting were very common in old Little Rus" [28, p. 577].

Portraits of the representatives of Cossack Elite give reasons to consider them to be an attribute of a funeral culture, because they were usually created not only for generic galleries, but in the context of the "last" moments in human life such as death and posthumous memory [33, p. 24].

Unfortunately, the portraits that were in the churches were then taken from there by the order of the Synod, and if the connoisseurs did not find them, "they were usually folded down at the bell tower and they decayed there" O. Lazarevskyi noted in the late 19th century [16, p. 337].

The portrait of Mykhailo Breslavets, a founder of a village Velyka Bahachka in the Poltava region, who died in 1644, was placed in the church of the Birth of Mother of God: "A portrait painted on canvas is hung in frames. Its height is an arshin, and its width is $3 / 4$ of an arshin. It is painted with oil paints and it depicts an old man in the position of a praying in front of a cross, he kneels down and he squeezes his hands. There is an inscription at the top of the portrait: "Mikhail Breslavets died here, a Cossack of his royal favor on 15th December, 1644" [15, p. 358].

The portraits of Pryluky Colonel Ivan Storozhenko and Bunchuk Comrade Hryhorii Storozhenko at the end of the 19th century were in V. V. Tarnovskyi collection [30, p. 167-168]. The appointment of the first of them for the funeral ritual is evidenced by the image of the Crucifixion and the Gospel, as well as the inscription. On the portrait of Hryhorii Storozhenko, under the image of the coat of arms, a poetic epitaph is placed:

"Luna v noshchi svetit, volk tune bludit zriashch,

Kresta Khristova vernym svet yest v noshchi i vo dni svetiashch;

Grigoriy Storozhenko, muzh sey znamenityy,

Imel te $\mathrm{v}$ gerbe svoyem znaki rodovity: 
Bezvredno ubo yemu za simi svetily

Shestvovat v nebesnago otchestva predely" [29, p. 578].

It is known that "above the coffin" of the General Judge Ivan Domontovych was also placed a portrait that was lost then. Having lived a long and violent life, having started his service as a Cossack Centurion and completing it as a General Judge, Ivan Domontovych began to prepare for his "last path" in traditions of that time. He became a founder of Baturyn Mykolaiv Krupytskyi Monastery. He built Mykolaiv Cathedral in it and he found his last refuge here after his death in 1683 .

On the portrait, the General Judge Ivan Domontovych was depicted standing next to the table on which the cross was placed. He had rosaries in his left hand, and a sign of the rank of judge in the right ... There was a miniature image of Krupytskyi monastery under the portrait and the inscription on both its sides:

"Khto na toy obraz poglianet

A shchom za ch (chelovek) byval vedati zhelayet, -

Veday, izh vernyy syn otchizny bylem,

Onoy z molodykh let verne sluzhilem.

Ioann imia mne ot Boga danno,

Domontovichem proimenovano.

Sud yeneralniy na mne zalezhal,

Kotoriy uriad do smerti doderzhal.

V meni svoim koshtom tserkov zmurovalem

A potom Bogu v rutsi dukha dalem" [16, p. 337].

Shyrotskyi K. confirmed that this portrait "was painted in 1705 on the basis of the gravestone portrait of Domontovych that may also have been made not from alive person, but from memory after death" [35, p. 198-202].

Authorship of the epitaph on the gravestone portrait of Ivan Domontovych belongs to D. Tuptalo, who was an abbot of Baturyn Mykolaiv Krupytskyi Monastery at that time. The portrait of I. Domontovych dated 1683 was kept in the Cathedral Church of Baturyn Mykolaiv Krupytskyi Monastery. In the second half of the 50 's of the 18th century the monastery came to its complete decline, as it was indicated by the then abbot Feofil, who began repair works in the main temple of the monastery. When Varsofonii Palmovskyi 
was the abbot (1763-1775), the reconstruction of the dwelling was completed. Obviously, in connection with repair works in the temple there was a need to restore the damaged portrait of the founder Ivan Domontovych.

It is known that later, the portrait was kept for a long time in the building of the abbot, where Filaret Humylevskyi saw it: "There was a Judge Domontovych on the portrait. He was an old man with clever eyes, with a kind face, with thick eyebrows, with curly hair. There was his coat of arms here: the sword turned to the bottom, between two quarters of a moon and two stars" [18].

About the ritual appointment of a portrait of Starodubsk Colonel Mykhailo Myklashevskyi testified to the inscription on it: "Mykhailo Myklashevskyi a Starodubsk Colonel a blessed and a founder of this Vidiubitskyi Holy Monastery. He was killed by Swedes in Polish city Niesvezhu in the battle of 1706 . He is buried in this temple. We wish timeless God's Memory to Him" [33, p. 146].

It is known that Mykhailo Myklashevskyi built a stone church of St. Heorhii and a stone refectory with a church of St. Transfiguration of the Lord in Vydubytskyi Monastery at his own expense. The portrait of a Colonel was made for this monastery [13, p. 243-244].

General Oboznyi Vasyl Dunin-Borkovskyi in the portrait, placed "above the grave" in Uspenskyi Cathedral of Yeletskii Monastery, is depicted in full height with a pernach and a sword. The icon of Mother of God and the family coat of arms are depicted behind it. In 1717 , along with the portrait, a copper silver plated tablet with an epitaphical inscription of Chernihiv Archbishop, Ioan Maksymovych, was placed that contained a list of temples, "for decoration of which Borkovskyi made a lot of donations" [14, $p$. 530-536]. Chernihiv Chronicle reports on the time of death and burial place: "Borkovskyi a Cossacks General Oboznyi died on 4th March, 1702. He was buried in Chernihiv Yeletskii Monastery in the porch on the right side". The earliest mention of the portrait of Vasyl Dunin-Borkovskyi is contained in the paper of O. Shafonskyi "Topographical description of Chernihiv homeland" in 1786 [28].

Adruh A. noted that this portrait is a painted monument to a deceased over its grave [1, p. 104]. P. Biletskyi believed that the author may have been a monk who was a painter of one of Chernihiv 
monasteries, and that the gravestone portrait belonged to the artistic ensemble of Uspenskyi Cathedral of Yeletskii Monastery in Chernihiv.

Above the grave near the wall of the Holy Cross church on the territory of the Kyiv-Pechersk Lavra of Poltava Colonel Pavlo Semenovych Hertsyk was placed his portrait with the inscription: "Portrait of the noble man of Poltava Colonel Pavel Gertsik, the founder of this Holy Temple, who he was buried in this place in it" [24, p. 18-41].

The author of the publication "Kiev old" of the story "To the portrait of Savva Grigorievich Tuptalo" reportered: "Over the grave of the pious Centurion his exact bust portrait on the canvas was hung immediately after his death on the wall" with the inscription "Savva Tuptalo, a Centurion of Kiev lived in lower Kiev city. He joined the majority at the age of one hundred and three years old, on the day of the Epiphany of the Lord, at three p.m., in 1703, and was buried in Kiev St. Cyril's Monastery, the founder of which he was" [10, p. 194-198].

The National Museum of Ukrainian History preserved a pair portrait of the General Judge V. Kochubei and the notable military comrade I. Iskra with the epitaph. They are depicted in praying position. An executioner with an ax is near them and a crowd of people watching the execution are around. The date and place of the execution are at the end of the epitaph (15th July, 1708, near Bila Tserkva) and the burial place (17th July, 1708, on the territory of Uspenskyi Cathedral of the Kyiv-Pechersk Lavra) [23, p. 69].

The portrait of the wife of Novhorod-Siverskyi Centurion Evdokiia Zhoravko also attracted the attention of the researchers: "The headstone of a deceased Evdokiia Lukyianova in the newly established Holy Trinity Church in 1697" K. Shyrotskyi noted in this connection: "It is evident that this is a true portrait that was carried behind her coffin" [35, p. 198-202].

At the beginning of the 20th century D.I. Yavornytskyi discovered the gravestone portrait of Mirhorod Regimental Oboznyi Vasyl Rodzianka with the inscription: "Vasiliy Rodzianka a Mirhorod Regimental Oboznyi joined the majority in December evening, 1732. He was eighty years old". D. Yavornytskyi also discovered a similar portrait of Stefan Rodzianka with the coat of 
arms and the inscription: "Stefan Rodzianka a Mirhorod Oboznyi died at the age of fourty-nine years old" [21, p. 107-109].

The portrait of Hetman Ivan Skoropadskyi is of the same type, on which, according to K. Shyrotskyi, "a face of a deceased is painted by the other person than everything else" [35, p. 198-202]. Hetman was buried in the crypt of the Harlampiivska Church of the Hamaliivskyi Monastery. The white stone carved grave plate with the inscription: "Here is the body of the servant of the God Ioan Skoropadskyi. He was the hetman of Zaporozhian troops, the founder of this monastery. He joined the majority in Hlukhiv on 3rd July, 1722"remained. The portraits of Anastasiia and Ivan Skoropadskyi are now preserved in the Sumy Art Museum [9, p. 112].

Lazarevskyi O. supposed that "the fee for the portrait work was comparatively low", but sometimes basis there were some misunderstandings on this. The fragment of the complaint that was given to P. Polubotok in 1722 by a Hlukhiv painter Hryhorii concerning the eldest son of a deceased General Judge O. Turanskyi, which died in 1716, who did not pay for the portrait: "I am complaining of your authority and I will ask the holy justice of Aleksey Turanskiy because of the fact that I wrote a portrait after the death of his father a General Judge. But Mr. Aleksey didn't pay me". O. Lazarevskyi noted that the portrait of a General Judge O. Turanskyi was painted after his death, that means "from a deceased" [16, p. 338].

It is probable that the portraits were created both by single painters, and by the representatives of workshops of painters. In particular, it is known that 43 such masters lived in the Starodubsk region. There were 36 specialists and 7 students. They belonged to the bourgeoisie, the Cossacks and the clergy [27, p. 110-114].

Thus the burial portraits depicting the representatives of the Cossack Elite are a "ticket" to the spiritual and material world of the leading social stratum of the 17th-18th centuries, to the world of a man standing on the verge of eternity.

Gravestone portraits of the representatives of the Cossack Elite appeared under the influence of the neighboring Polish-Lithuanian Commonwealth, but they were original by their character. Subsequently, the traditions to depict a deceased were spread in 
Russia. M. Khanenko noted an interesting observation, while he was in service of Hetman I. Skoropadskyi in Moscow. During the magnificent funeral ceremony of Prince V. Golitsyn, he saw the portrait of a deceased and the epitaph on a white gonfalon [11, p. 77]. Aleksieieva M. remarked that "the Russians could have witnessed mourning ceremonies of Poles and Ukrainians more than once ... Cossacks' traditions in that area ... were very similar to the Polish ones" [6, p. 70-73].

Consequently, the gravestone portraits should be considered to be a part of the Cossack Elite's funeral culture. Having made a will, having chosen the place of the "last asylum", having distributed the property between the relatives, temples and monasteries, having taken care of the memorial ceremony, the representatives of the Cossack Elite ordered the gravestone portraits that were placed in temples above the grave. A gravestone portrait could also be ordered after death by the relatives in order to perpetuate the memory of a deceased.

The use of portraits in a mourning ceremony had several reasons. First of all, the portrait "enlivened" a deceased, allowing him to appear for the last time during farewell to his relatives and the world. It was also a way of memory perpetuating of a deceased, an occasion to recall his activity as a founder and a philanthropist.

\section{References}

1. Adrug, A. (2013), Painting of Chernigov of the second half of XVII - early XVIII centuries, Chernihiv.

2. Bileczkyi, P. O. (1969), Ukrainian portrait painting of the XVIIXVIII centuries: Problems of formation and development. Mystecztvo, Kyiv.

3. Horlenko, V. (1882), "Old Little Russian Portraits", Kyevskaya staryna, № 10, pp. 602-606.

4. Gava, O. (2007), "Cossack portraits in the funds of the Odessa State History and Local History Museum", Chornomorska mynuvshyna. Zapysky viddilu istoriyi kozacztva na Pivdni Ukrayiny, Feniks, Odessa, pp. 184-185.

5. Dmytriienko, M., Pokhodiashcha, O. (2010), "Portrait painting as a source of genealogical research by O. M. Lazarevskyi", Specialni istorychni dyscypliny: pytannya teoriyi ta metodyky. Genealogiya ta geraldyka. Zbirka naukovyx pracz, № 1, pp. 95-110.

6. Zverkhovska, A. (2006), "Ukrainian portrait in the National Art Museum", Kupola, №3, pp. 70-73. 
7. Ivanova, B. (2005), "Medieval components in the structure of the pictorial portrait at the dawn of the New Age in the countries of Eastern and South-Eastern Europe", Acta Slavica Iaponica, № 22, pp. 215-237.

8. History of Rus (1991), Veselka, Kyiv.

9. Pictures of the church life of the Chernihiv Diocese from the 9th century's history (1911), Typography S. V. Kulzhenko, Kyiv.

10. "To the portrait of Savva Grigorievich Tuptalo" (1882), Kyevskaya staryna, № 7, pp. 194-198.

11. Kosiv, R. (2009), Ukrainian gonfalons XVII-XVIII centuries, Oranta, Kyiv.

12. Kovalova, M. (2009), "Orthodox traditions in the Cossack portraits of Central and Eastern Ukraine in the late XVII-XVIII centuries", Artistic culture: actual problems, № 6.

13. Lazarevskyi, O. (1882), "Miklashevsky". Kyevskaya staryna, № 8, pp. 243-244.

14. Lazarevskyi, O. (1894), "General Oboznyi Vasyl Dunin-Borkovskyi 1640-1702: To the portrait", Kyevskaya staryna, № 3, pp. 530-536.

15. Lazarevskyi, O. (1894), "Historical trivia", Kyevskaya staryna, № 5.

16. Lazarevskyi, O. (1882), "Old little Russian portraits", Kyevskaya staryna, №5, pp. 337-342.

17. Lazarevskyi, O. (1882), "Old little Russian portraits", Kyevskaya staryna, № 10, pp. 173-174.

18. "Men's Monasteries" (1873), Historical and statistical description of the Chernigov diocese, Chernihiv.

19. Netudykhatkin, I. (2010), "Reverence of religious patrons in the Orthodox churches of Kyiv and Left Bank Ukraine in XVIII-XIX centuries: regulatory and legal aspects", Gileya: naukovyj visnyk: Zbirnyk naukovyx pracz, № 36, pp. 5-9.

20. Ogloblyn, O. (1960), Hetman Ivan Mazepa and his er, New York.

21. Osadcha, Yu. (2005), "Portraits of historical figures of the Cossack era in the collection of the Dnipropetrovsk National Historical Museum named after. D.I. Yavornytsky", Grani, № 5, pp. 107-110.

22. Pokhodiashcha, O. (2011), "The influence of the church on the development of Ukrainian portrait painting in the seventeenth and eighteenth centuries", Ukrayinoznavstvo, № 3, pp. 78-82.

23. Pokhodiashcha, O. (2013), "Prior to the history of the trunk line in honor of V. Kochubey and I. Iкskra", Novi doslidzhennya pamyatok kozaczkoyi doby v Ukrayini: Zbirnyk naukovyx pracz", Kyiv, № 22 (2).

24. Procenko, L. (1995), "Burial of the Kiev-Pechersk Lavra", Kyyivska starovyna, № 2, pp. 18-41. 
25. Puczko, V. G. (2008), "Portraits of Tobolsk Metropolitan John Maximovich", Problems of the history of Russia, Ekaterynburg, № 2, pp. 258-264.

26. Semeniuk, D. (1997), "Collection of nude portraits from the funds of the Lviv Historical Museum", Naukovi zapysky Lvivskogo istorychnogo тиzеуu, Lviv, pp. 48-61.

27. Soloviy, O. (1917), "Before the history of Ukrainian painting on the cob of the eighteenth century", Ukraine, № 1, pp. 100-114.

28. Shafonskyj, A. (1851), Chernigov subdistrict topographical description with a brief geographical and historical description of Minor Russia, of which parts of the same homeland is composed, 1786. Kiev.

29. Storozhenko, A. (1882), "Old Little Russian Portraits", Kyevskaya staryna, № 9, pp. 577-579.

30. Storozhenko, M. (1890), "The portraits of Pryluky Colonel Ivan Storozhenko and Bunchuk Comrade Hryhorii Storozhenko", Kyevskaya staryna, № 4, pp. 167-173.

31. Sukhovarova-Zhornova, O. (2004), "Typological characteristic of historical portraits of the XVII-XVIII centuries", Specialni istorychni dyscypliny: Pytannya teoriyi ta metodyky: Zbirnyk naukovyx pracz, № 11, pp. 244-278.

32. Tananaieva, L. (2008), "Gravestone portrait in the lands of the Polish-Lithuanian Commonwealth XVI-XVII centuries", Kategoryy zhyzny y smerty v slavyanskoj kulture, Moscow, pp. 69-92.

33. Ukrainian portrait of the XVII-XVIII centuries: Catalog-album (2006), Kyiv.

34. Shherbakivskyi, D., Ernst, F. (1925), Ukrainian portrait. Exhibition of the Ukrainian portrait of the XVII-XX centuries, Kyiv.

35. Shyrotskyi, K. (1914), "Something about old portraits", Syajv, № 4 7, pp. 198-202.

36. Chroscicki, J. (1974), Pompa funebris. $Z$ dzejow kultury staropolskie, Warszawa.

Попружна А. В.

УВІЧНЕННЯ ПАМ'ЯТІ В НАДГРОБНИХ ПОРТРЕТАХ ЯК АТРИБУТ ПОХОВАЛЬНОЇ КУЛЬТУРИ КОЗАЦЬКОЇ СТАРШИНИ ДРУГОЇ ПОЛОВИНИ ХVII-ХVIII СТ.

У статті розглянуто надгробні портрети представників козацької старшини другої половини XVII-XVIII cm. як атрибути ї̈ поховальної культури.

Метою статті є аналіз механізмів увічнення та вшанування пам'яті померлих представників козацької еліти, з'ясування ролі місцевих традицій та зовнішніх впливів у формуванні поховальної культури козащької стариини другої половини XVII-XVIII $\mathrm{cm}$. 
Дослідження надгробних портретів сприятиме кращяому розумінню поховальної культури як сочіокультурного феномена ранньомодерної доби, який містив підготовку до смерті, жалобні церемонії та увічнення й вшанування пам'яті померлих.

Зроблено висновок, щуо представники провідної сочіальної верстви Гетьманщини ще за життя замовляли надгробні портрети, дотримуючись забобону домальовувати обличчя портретованого після його смерті. Надгробні портрети могли замовляли й рідні після смерті родича. Використання портретів у жалобній церемонї було способом увічнення пам'яті та приводом нагадати про благодійниитво померлого.

Ключові слова: поховальна культура, козачька старшина, надгробний nopmpem.

\section{Список використаних джерел}

1. Адруг А. Живопис Чернігова другої половини XVII - початку XVIII століть. Чернігів. 2013. 182 с.

2. Білецький П. О. Український портретний живопис XVIIXVIII ст.: Проблеми становлення і розвитку. Київ: Мистецтво. 1969. 319 c.

3. Горленко В. Старинные малороссийские портреты. Киевская старина. 1882. № 12. С. 602-606.

4. Гава О. І. Козацькі портрети у фондах Одеського державного історико-краєзнавчого музею. Чорноморська минувшина. Записки відділу історї козацтва на Півдні України. Одеса: Фенікс. 2007. Вип. 2. C. $184-185$.

5. Дмитрієнко М., Походяща О. Портретний живопис як джерело генеалогічних досліджень О. М. Лазаревського. Спеціальні історичні дисцииліни: питання теорії та методики. Генеалогія та геральдика: збірка наукових праць. Київ: Інститут історії України. 2010. № 1. C. 95-110.

6. Зверховська А. Український портрет у Національному художньому музеї. Купола. Київ. Вип. 3. С. 70-73.

7. Иванова Б. Средневековые компоненты в структуре живописного портрета на заре Нового времени в странах восточной и юговосточной Европы. Acta Slavica Iaponica. Hokkaido University. 2005. C. 215-237.

8. Історія Русів. Київ. Веселка. 2006.

9. Картины церковной жизни Черниговской Епархии из IXвековой ее истории. Київ: Типография С. В. Кульженко. 1911. 206 с.

10. К портрету Саввы Григорьевича Туптало. Киевская старина. 1882. № 7. С. 194-198.

11. Косів Р. Українські хоругви XVII-XVIII ст. Київ: Оранта. 2009. 372 c. 
12. Ковальова М. Православні традиції в козацьких портретах Центральної і Східної України кінця XVII-XVIII ст. Художня культура: Актуальні проблеми. Київ. 2006. Вип. 6. С. 229-239.

13. Лазаревский А. Миклашевские. Киевская старина. 1882. № 8. C. 243-244.

14. Лазаревский А. Генеральный обозный Василий Касперович Борковский 1640-1702: к портрету. Киевская старина. 1894. № 3. C. $530-536$.

15. Лазаревский А. Исторические мелочи. Киевская старина. 1894. № 5. C. 358 .

16. Лазаревский А. Старинные малороссийские портреты. Киевская старина. 1882. № 5. С. 337-342.

17. Лазаревский А. Старинные малороссийские портреты. Киевская старина. 1882. № 10. С. 173-174.

18. Мужеские монастыри. Историко-статистическое описание Черниговской епархии. Чернигов: Губернская типография. 1873. Кн. 3. $392 \mathrm{c}$.

19. Нетудихаткін I. Шанування церковних благодійників у православних храмах Києва та Лівобережної України XVIII-XIX ст.: нормативно-правовий. Гілея: збірник наукових праць. Київ. 2010. Вип. 36. C. 5-9.

20. Оглоблин О. Гетьман Іван Мазепа та його доба. Нью-Йорк: Видання Організації Оборони Чотирьох Свобід України та Ліги Визволення України. 1960. 408 с.

21. Осадча Ю. А. Портрети історичних діячів козацької доби у колекції Дніпропетровського національного історичного музею ім. Д.І. Яворницького. Грані. 2005. № 5. С. 107-110.

22. Походяща О. Вплив церкви на розвиток українського портретного живопису XVII-XVIII століть. Украӥнознавство. 2011. № 3. C. $78-82$.

23. Походяща О. До історії створення епітафії на честь В. Кочубея та I. Іскри. Нові дослідження пам'яток козацької доби в Украйні: збірник наукових праџь. Київ; Нікополь. 2013. Вип. 22. Ч. II. 270 с.

24. Проценко Л. Поховання Києво-Печерської Лаври. Київська старовина. 1995. № 2. С. 18-41.

25. Пуцко В. Г. Портреты Тобольского митрополита Иоанна Максимовича. Проблемь истории России. Екатеринбург: Волот. 2008. Вып. 7: Источник и его интерпретации. С. 258-264.

26. Семенюк Д. Колекція натрунних портретів з фондів Львівського історичного музея. Наукові записки Львівського історичного музею. Львів. 1997. Вип. 6. Ч. 1. С. 48-61. 
27. Соловій О. До історії українського живопису на початку XVIII століття (Кілька слів про Синодальний догляд за іконописанням на Україні). Україна. 1917. № 1-2. С. 100-114.

28. Шафонский А. Черниговского наместничества топографическое описание с кратким географическим и историческим описанием Малой России, из частей коей оное наместничество составлено, 1786 г. Киев. 1851. 697 с.

29. Стороженко А. Старинные малороссийские портреты. Киевская старина. 1882. № 9. С. 577-579.

30. Стороженко Н. Полковник Прилуцкий Иван и бунчуковый товарищ Григорий Стороженки. Киевская старина. 1890. № 4. С. 167-173.

31. Суховарова-Жорнова О. Типологічна характеристика історичних портретів XVII-XVIII ст. Спецііальні історичні дисцииліни: Питання теорії та методики: збірник наукових праць. Київ. 2004. № 11: у 2 ч. Ч. 2. С. 244-278.

32. Тананаева Л. И. Нагробный портрет в Речи Посполитой (XVIIXVIII вв.). Искусствознание. 2007. № 1-2. С. 304-342.

33. Український портрет XVI-XVIII століть: каталог-альбом. Київ: Артанія Нова; Хмельницький: Галерея. 2006. 351 с.

34. Щербаківський Д. Український портрет. Виставка українського портрету XVII-XX ст. Київ. 1925. 61 с.

35. Широцький К. Дещо про давні портрети. Сяйво. 1914. Ч. 7-9. C. $198-202$.

36. Chroscicki J. Pompa funebris. Z dzejow kultury staropolskie. Warszawa, 1974. $365 \mathrm{~s}$. 